\title{
Some bioecological aspects of the rose aphid, Macrosiphum rosae (Hemiptera: Aphididae) and its natural enemies
}

\author{
Mohsen MEHRPARVAR, ${ }^{1}$ Seyed Mozaffar MANSOURI, ${ }^{2}$ \\ Bijan HATAMI ${ }^{3}$ \\ ${ }^{1}$ Department of Biodiversity, Institute for Science, \\ High Technology \& Environmental Sciences, \\ Graduate University of Advanced Technology, Kerman, Iran \\ E-mail:mehrparvar@aphidology.com; aphidology@gmail.com \\ ${ }^{2}$ Department of Biodiversity, Institute for Science, \\ High Technology \& Environmental Sciences, \\ Graduate University of Advanced Technology, Kerman, Iran \\ ${ }^{3}$ Emeritus Professor, Department of Plant Protection, \\ College of Agriculture, Isfahan University of Technology, Isfahan, Iran
}

Manuscript received Sept. 17, 2016; revised Sept. 28, 2016; Accepted Oct. 09, 2016

\begin{abstract}
The rose aphid, Macrosiphum rosae, is one of the most important pests on roses in the world and it causes economic damage. In this study, biology, seasonal population dynamics, and status of natural enemies of the rose aphid were studied. Seasonal population dynamics was studied by randomly sampling 10 shoots every week in two locations of Isfahan, Iran. Rose aphid with a high population density, both in spring (April and May) and in autumn (November), was observed on roses. The results showed that the rose aphid overwinters as parthenogenetic females and nymphs. This aphid migrates to a secondary host, Dipsacus fullonum (Dipsacaceae), in summer due to poor food quality of rose plants. Since sexual form and egg of the rose aphid were not observed in Isfahan, it is probably anholocyclic species with host alternation in this area. Natural enemies of the rose aphid include four species of Coccinellidae, three species of Syrphidae, two species of Chamaemyiidae, one species of Chrysopidae, a few species of Anthocoridae and Miridae, and one species of Cantharidae. One species of ectoparasite mite of Erythraeidae was also collected. In addition, four species of parasitoid wasps, Braconidae, were collected.
\end{abstract}

Keywords: seasonal fluctuations, population dynamics, predator, parasitoid, pest 


\section{Introduction}

Rose is one of the most beautiful ornamental flowers in the world, and as such it can be found in many houses and gardens in cities due to its especial characteristics such as stability, long period of floral initiation, different varieties, and, of course, its beauty [1]. Rose as a plant is found everywhere and is cultivated widely in most parts of the world. Furthermore, cut rose flower is regarded as one of the best cash crop ornamental flowers. Rose is attacked by numerous pests; amongst them, aphids are considered as a major pest. Aphids have a very successful worldwide distribution [2,3]. Their damages to plants may be direct or indirect: direct damage is due to aphids' intense feeding on plant sap, which will wilt the plant and decrease the yield; indirect damage comes as a result of honeydew excretion and virus transmission. Excretion of honeydew promotes the growth of sooty mould on the plant surface, so photosynthesis will be disturbed and crop yield will be decreased $[2,4]$.

The rose aphid, Macrosiphum rosae (Linnaeus, 1758) is a cosmopolitan species due to the world-wide cultivation of roses [4-7]. This aphid is the most important pest of roses and is probably native to Eurasia and it causes significant economic damage $[6,8]$. This aphid has been distributed in all parts of Iran with high economic importance [9]. There is little knowledge on the biology and ecology of this pest in Iran. In other countries, several studies have been performed in this field [e.g. 6, 10-15], but according to the climatic conditions of the given regions different results were obtained. Three life cycles have been observed for this aphid [4-6]: A) Holocyclic: its sexual morphs are produced in autumn and overwintering occurs in the egg stage. In summer, the aphids emigrate from roses as primary host plants to secondary host plants and aestivate on them. In early autumn, they return again to the primary host plants to produce sexual morphs. Migration of this aphid to secondary host plants of Dipsacaceae in summer is unavoidable [16]. B) Holocyclic: in this case, the rose aphid remains on the rose bushes during the whole year without any migration, and overwinters as eggs on the roses. C) Anholocyclic: there are no sexual morphs or egg stage, and it overwinters as parthenogenetic females on the roses.

Eastop and Hodjat [17] observed that rose aphid activates in Khuzestan province (southern part of Iran) from March to June on the terminal buds and leaves of different roses. They mention that rose aphid is observed in the mountainous and cold regions of Iran on roses from April to November with a high population in early spring. There is no report about the oviparous females of this aphid in Iran. Eastop and Hodjat (1980) reported that probably this aphid overwinters in egg stage in the Alborz Mountain and in very cold regions of Iran. In addition, in hot and dry regions of Iran, such as Khuzestan, M. rosae reproduces parthenogenetically throughout the whole year [17]. 
Since rose aphid is of particular importance because of its economic damage, investigation and bioecological studies on this aphid and those factors affecting its population dynamics are fundamental and very significant steps in gaining better knowledge to control it. Therefore, this study was designed to investigate the population fluctuations of $M$. rosae on roses under field condition in Isfahan, central part of Iran, and determine its natural enemies.

\section{Materials and methods}

\section{Sampling regions}

Two locations in Isfahan, a central region of Iran, were selected for studying the bioecology and seasonal changes of the rose aphid population. The first location was Ghadir Park in the eastern part of Isfahan with the perennial rose bushes. The altitude of this region was about $1,570 \mathrm{~m}$, with a latitude of $32^{\circ} 38^{\prime}$ and a longitude of $51^{\circ} 42^{\prime}$. The numerous rose bushes were available and most of them were hybrid tea variety of rose. In this area, there were also numerous ornamental trees such as elm, pine, plane, varnish, and locust trees. Sampling began on April 30, 2003.

The second location of sampling was the Campus of Isfahan University of Technology (IUT). The altitude of this region was about $1,600 \mathrm{~m}$, with a latitude of $32^{\circ} 42^{\prime}$ and a longitude of $51^{\circ} 32^{\prime}$. There was a rose garden with 130 rose bushes. There were various fruit trees such as grape, pomegranate, apple, pear, almond, berry, fig, and some ornamental trees as pine, elm, and plane trees. Furthermore, various vegetables and summer crops were cultivated in this area. The IUT weather station, close to the garden, provided us with the climatic data.

The water logging method of irrigation of rose plants was used in both places of sampling to avoid any impact on the population of aphids.

\section{Sampling method and counting the aphids}

Seasonal fluctuation of the rose aphid population was determined by weekly sampling for 19 months from April 2003 to November 2004. Every week, at each place of sampling, 10 rose bushes were selected randomly; one twig of each rose bush was cut at random as sampling unit. Since most of the rose aphid colonies are located along a length of $10-15 \mathrm{~cm}$ on the terminal part of twigs, $15 \mathrm{~cm}$ of the terminal portion of twigs was selected and cut off. In laboratory, the nymphs and adults were counted separately using stereomicroscope. Data from each collection date were transformed into $\log _{(\mathrm{n}+1)}$ to stabilize variance and three-point moving 
averages were used to visualize seasonal trends. The graphs were produced using Microsoft Excel 2010.

\section{Determining secondary host plants}

According to the reports of other researchers, M. rosae in other regions of the world migrates to secondary host plants in summer [4-6]. So, in this study, from early June, when aphid populations are decreasing, different plants in Isfahan and around the sampling locations, especially those plants mentioned as secondary host plants in the literature [e.g. 4-6, 18, 19], were identified and thoroughly examined (at least three times per month) as to whether there is rose aphid or not. Since the rose aphid may have spent the summer furtively on the rose plant, especially inside the collar, some parts of the plant, especially the collar and top levels of the roots were also checked carefully in addition to the weekly sampling of twigs. If an aphid was found on these plants, it was collected by a paint brush in a vial of $80 \%$ ethanol, and then identified in the laboratory.

\section{Determining place and stage of overwintering}

To do so, rose bushes in both sampling places were visited and examined by weekly sampling from mid-September. Since rose plants were the primary hosts of the rose aphid, there were two possibilities for the overwintering of the rose aphid on this plant; it either spends the winter as egg on the rose bushes or overwinters as viviparous female. To determine the existence of the sexual form of the aphid and the existence of egg on the plant tissues, plant sampling was done in a way that different parts of the plant, including twigs, branches, upper parts of root, and collar, were cut with pruning shears and put in a plastic bag to be examined by stereomicroscope in laboratory. Female sexual morphs are easily recognizable for their swollen hind tibia with pseudorhinaria on it [5].

\section{Collecting and identifying natural enemies}

Natural enemies of rose aphid were collected in different regions of Isfahan, especially in designated sampling regions. Since rose aphid, like other aphids, has many natural enemies from various orders and families of insects, a special method was used for collecting each group. Ladybirds and predatory bugs were collected using paint brush, insect net, and aspirator, and kept in $80 \%$ ethanol. Other rose aphid predators, such as the larvae of Syrphid flies, the larvae of Chamaemyiid flies, and the larvae of green lacewings, were collected with paint brush from the rose bushes, and then transferred to laboratory. For identifying these predators, they were reared until maturity. To rear these larvae in laboratory, they were put in glass petri dishes with a diameter of $11 \mathrm{~cm}$ and a height of $2 \mathrm{~cm}$ with a filter paper 
on its bottom. Then, they were fed with rose aphids. The petries were kept in an incubator at $25 \pm 1{ }^{\circ} \mathrm{C}$. $2-3$ days after the emergence of adults, they were transferred to vials with $80 \%$ ethanol. Afterwards, they were identified at the family level and were sent to specialists for identification at the species level.

Collection of the rose aphid parasitoids was quite different from its predators. To do so, at first, the available aphid colonies on the roses in nature were examined, and after observing some parasitized aphids the twigs having these aphids were cut off, and they were reared until the emergence of parasitoids. At the laboratory, twigs were kept in small vials of water in incubator at $25 \pm 1^{\circ} \mathrm{C}$. The emerged parasitoids were kept in small vials containing $80 \%$ ethanol and identified at the family level. These parasitoids were also sent to specialists for identification.

\section{Results and discussions}

\section{Biology and seasonal fluctuations}

Seasonal fluctuations of the rose aphid in two sampling regions, the Campus of IUT and the Ghadir Park, are shown in figures 1 and 2 respectively. Weather information during our study (2003 and 2004) is presented in figures 3 and 4. When the cold weather of winter is over, and it gets warmer in the early growing season, the rose aphid population increases considerably, and thus in April and May very large and dense colonies can be observed on roses. The increase of population continued until mid-May. One of the reasons of population increase in spring is the suitable quality of the rose plant sap. Since in spring the vegetation growth of the rose plant begins and at this time it has tender and delicate tissues, this condition is very suitable for the growth of aphids [20]. The quality of aphid food (plant sap) is an important factor that can result in the increase of aphid population and acceleration of their growth [21, 22].

A large number of biological agents play an important role in the natural control of aphids $[3,21,23]$. At the beginning of the season, with the increase of the rose aphid population, some predators, such as ladybirds, predatory bugs, green lacewings, and also parasitoids, are active and play a considerable role in controlling the rose aphid population. On the whole, the role of natural enemies in reducing the population of this aphid in May cannot be denied since after the activity of natural enemies has begun the population of rose aphids is reduced. 


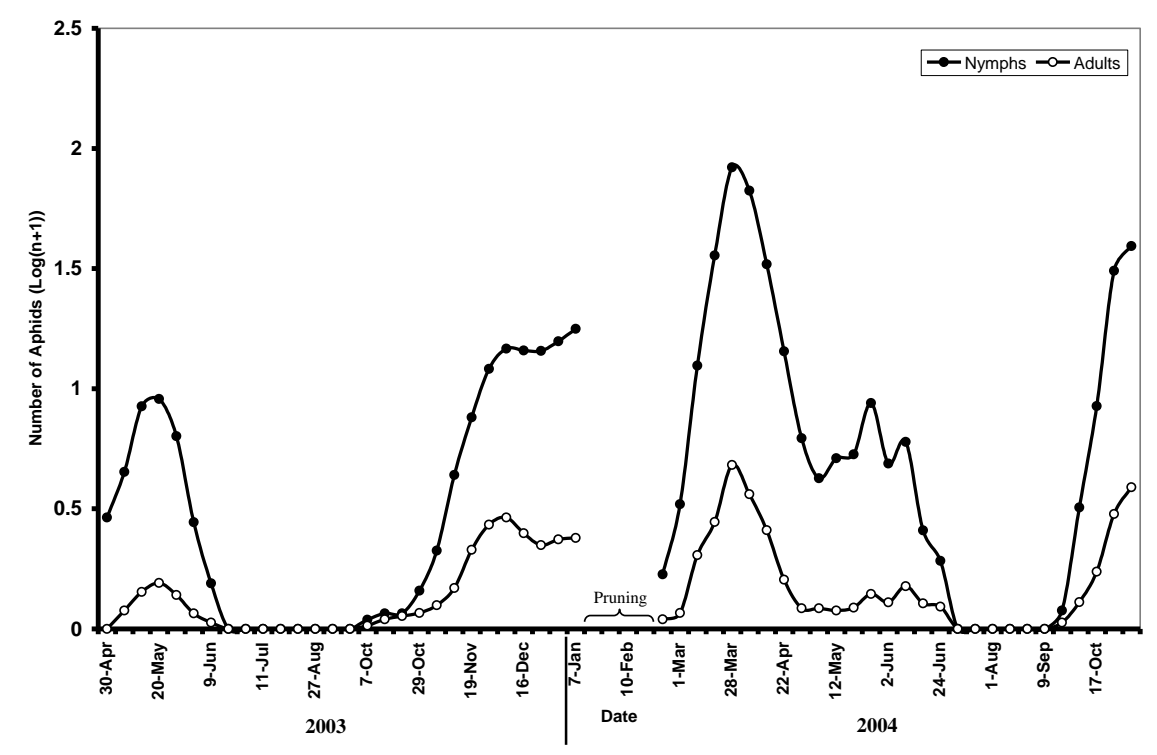

Figure 1. Seasonal fluctuations of the rose aphid, Macrosiphum rosae, in IUT Campus. Data from each collection date were transformed into $\log _{(\mathrm{n}+1)}$ to stabilize variance and three-point moving averages were used to visualize seasonal trends.

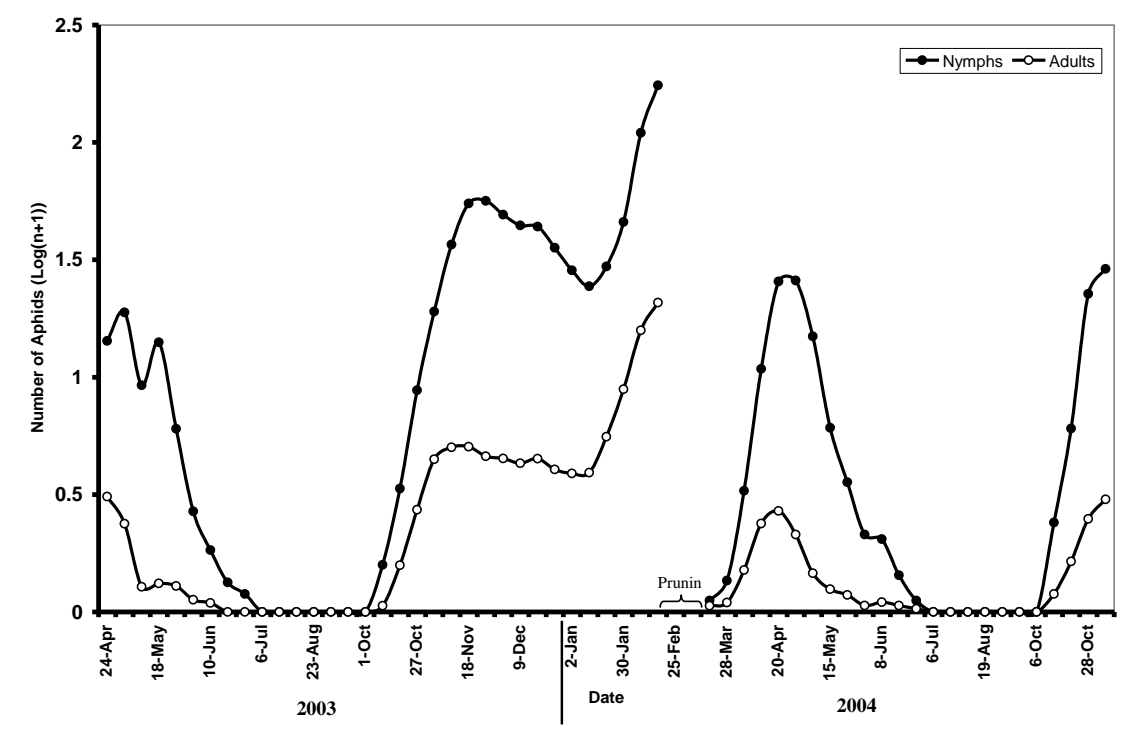

Figure 2. Seasonal fluctuations of the rose aphid, Macrosiphum rosae, in Ghadir Park. Data from each collection date were transformed into $\log _{(n+1)}$ to stabilize variance and threepoint moving averages were used to visualize seasonal trends. 
By late May, with the increase of temperature, the growth of the rose aphid and also its fertility decrease, which results in the decrease of the aphid population on the rose plants. The author's studies on the biology of the rose aphid at different temperatures [24], and also studies of Maelzer [6] on South Australia, demonstrated that the optimum temperature for the growth of the rose aphid is about $22{ }^{\circ} \mathrm{C}$. At temperatures higher than $22{ }^{\circ} \mathrm{C}$, the growth and fertility of the rose aphid is reduced severely. Temperature curves in the two years of study (fig-s 3 and 4) show that the average daily temperature is going up almost from the end of May from $22{ }^{\circ} \mathrm{C}$ and it drops under $22{ }^{\circ} \mathrm{C}$ at the end of September. These changes of temperature are exactly synchronized with the fluctuation of the population of $M$. rosae, meaning that at the end of May, when the average daily temperature goes above $22{ }^{\circ} \mathrm{C}$, the population of the rose aphid starts decreasing and also in early October the temperature drops under $22^{\circ} \mathrm{C}$, and the rose aphid population increases again.

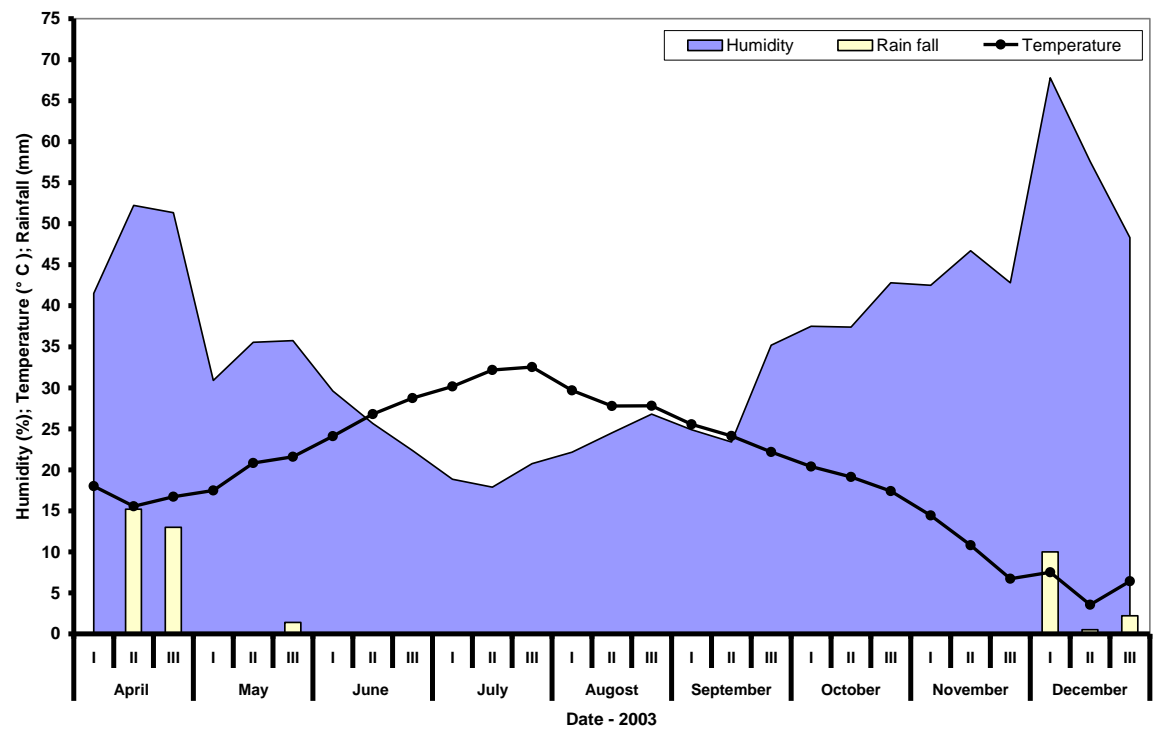

Figure 3. Weather information (mean of daily temperature, rainfall, and humidity) of Isfahan city in 2003 


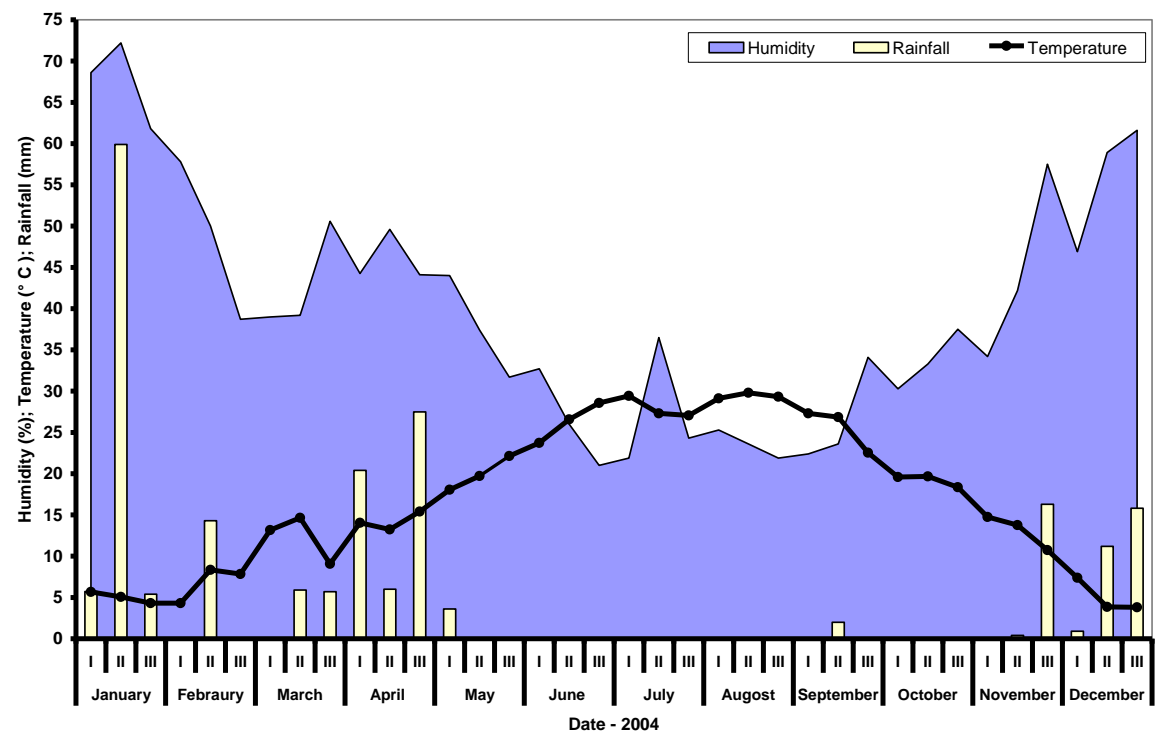

Figure 4. Weather information (mean of daily temperature, rainfall, and humidity) of Isfahan city in 2004

The temperature does not only have a direct influence on the rose aphid but it also changes the physiology of the rose plant, which results in the stagnation of the plant. So, it would not be a suitable food source for the rose aphid. Therefore, aphids have to migrate to their secondary host plants to avoid these unsuitable conditions. Results obtained by Maelzer (1977) and Jaskiewicz (1997) also confirm these cases $[6,16]$.

The decrease of population begins with the increase of temperature from the end of May and will continue so that there will be no rose aphid on the rose plants by the end of June. During summer, when the average temperature is more than 22 ${ }^{\circ} \mathrm{C}$, the rose aphid aestivates on its secondary host plant, Dipsacus fullonum (Dipsacaceae). It should be noted that Eastop and Hodjat (1980) published their personal observations that rose aphid can be found on roses in the cold and mountainous regions of Iran from April to November [17]. Nevertheless, the current study shows that in Isfahan rose aphids migrate to their secondary host plant in summer, where they aestivate. Therefore, it will not be found on roses from late June until early October. In mid-October, as the daily average of temperature in Isfahan is less than $22{ }^{\circ} \mathrm{C}$ (fig-s 3 and 4), alate aphids are produced and migrate towards the rose plant and establish new colonies. These colonies will continue their growth at the appropriate temperature of autumn, and their population increases. During this time of the year, with respect to the fact that 
natural enemies are intensely active, their role in the control of aphid population cannot be neglected. The increase of the rose aphid population will continue during autumn and, in fact, the beginning of the severe winter cold determines the time when the population growth is stopped. During this research, we found that in the climatic conditions of Isfahan the cold of winter could not have a considerable effect on the decrease of the rose aphid population. Macrosiphum rosae primarily produces its dense colonies on the rose at early spring and infests twigs and buds severely. From late spring and early summer, which is a warmer period, there will be more alate morphs, causing the spread of this pest to other rose bushes or resulting in migration to secondary host plants for aestivation. The population of this aphid is very low during summer, so that nearly no rose aphid is observed on the roses. In early autumn, which is cooler, these aphids return from their secondary host plants to the rose bushes, and produce new, dense colonies. Because of the cold weather in winter, the growth of these colonies is limited and the aphid population is decreased; this trend is also reported by $[6,9,25]$.

Temperature is one of the most important factors that affects the fluctuation of aphid populations [21, 26, 27]. Environmental temperature causes severe changes in the aphid population, and thus in summer, with the increase of the temperature, the number of aphid individuals is reduced very much on the host plants. Hot and dried climates, temperatures above $30{ }^{\circ} \mathrm{C}$, severe wind and rainfall reduce the population of this aphid on roses [16]. Our results show that rainfall has a considerable effect on the population dynamics of the rose aphid, so that the aphid population decreases severely after raining. The reasons for this matter lie in aphids being washed off by drops of rain, so that they cannot return to the plants again. Rainfall may cause nearly $100 \%$ mortality of adults and older nymphs [6]. The physiological conditions of the host plant are also very effective in the growth and increase of the rose aphid population [11]. In autumn, when migrant alate morphs are produced and migrate from the secondary host plants to their primary ones, first, newly established colonies can be observed on the bushes of dog-rose. In winter, since rose bushes do not have fresh twigs and buds, the rose aphid is transferred to the lower parts of the plant, especially to the lower surface of the remained leaves. Red adult individuals in a colony are darker than red spring individuals; however, some winter morphs are dark green or have some green spots on their bodies. In IUT, the decrease of the winter population began sooner than in Ghadir Park, which is probably due to the proximity of the IUT campus to the mountain and higher altitude, so the cold of winter of IUT is more severe than in Ghadir Park, which is located in the city of Isfahan.

Mainly three factors influence the dynamics and the structure of aphid populations including: A) The potential fertility of aphids influenced by the 
physiological condition of host. B) The density of population and climatic condition, which result in the production of winged morphs [28-30]. C) Presence and activity of predators and parasitoids $[11,31]$. But, because of the complexity of the system, there is no general or certain view about the relative importance and interactions of the active factors [11].

In addition to the rose aphid, which is the most important rose pest in Iran [9, 25] and the world [e.g. 5, 8], other aphids, such as Amphorophora catharinae (Nevsky, 1928) and Rhodobium porosum (Sanderson, 1900), are also active on roses in Isfahan with a very high population. These two species have considerable population in Isfahan and sometimes the number of observed colonies and their population is even greater than that of the rose aphid. The above mentioned species are active on the rose when it is warmer in summer. In autumn, the population of these aphids and of the rose aphid increases simultaneously. However, in autumn, in addition to these colonies, other small colonies of Aphis fabae Scopoli, 1763, and Aphis craccivora Koch, 1854 are also observed on roses. The activity of these species in autumn begins sooner than those of the rose aphid.

According to the reports [4-6, 11, 16, 32], M. rosae, depending on the region of activity, has three kinds of life cycles. So, if the climatic conditions of a region change severely and these fluctuations remain stable for a long time, the life cycle of the rose aphid and the way of its overwintering will probably change.

In the current study, we found that the rose aphid reproduced viviparously at the climatic conditions of Isfahan throughout the whole year, and there was no sexual form. It also migrated to its secondary host plant in summer. Accordingly, M. rosae is anholocyclic with host alternation in Isfahan.

Weekly observations revealed that the population of predators relatively increases at two time points of the year, in spring (May) and in autumn (October and November), while the rose aphid population decreases. It should be noted that the population of natural enemies is basically low early in the season, and after a while it increases. During this time, aphids can increase their population rapidly. However, when there is a delay for the appearance of natural enemies, especially coinciding with the increase of the aphids' population, they will not be effective, and these natural enemies will not be able to control the population of aphids. Overall, it can be said that fluctuations in the rose aphid population depend on the changes of climatic factors, the host condition, and the natural enemies during its activity.

\section{Secondary host plants}

One of the characteristics of the evolution of aphids' life cycle is host alternation $[4,5]$. On the whole, the distribution of the aphids on the plant or host plants or among them is determined according to the qualitative fluctuation of plant sap [21]. In this research, $M$. rosae in summer was collected only from the $D$. 
fullonum (Dipsacaceae). Dipsacus species are biennial plants with prickly stems and have divided branches at the top parts. This plant has been distributed in Iran especially in the northern, north-eastern, north-western, southern, and central parts of Iran [33]. This plant may be cultivated in the gardens of urban regions as an ornamental plant, which is partially scattered in Isfahan. Since the rose aphid is large and heavy, the possibility of the migration of this aphid from remote regions to the roses of the gardens in the city seems impossible. Although frequent visits demonstrated that the rose aphid was not available on other plants in summer, it is possible that this aphid spends the summer on other plants in addition to D. fullonum.

Various plants have been named as secondary host plants for the rose aphid. These plants are those hosts on which aestivation takes place, and most of them belong to families such as Dipsacaceae, Valerianaceae, and Onagraceae [4-6, 18, 19]. These plants belong to species such as Dipsacus sativuspilosus, D. strigosa, D. silvestris, D. fullonum, Succisa pratensis, and Knautia arvensis of the family of Dipsacaceae [4, 5, 8], Centranthus rubber, Centranthus sp., and Valeriana sp. of the family of Valerianaceae [5, 32], Chamaenerion and Epilobium of the family of Onagraceae [4]. Heie (1994) introduced Chamaenerium angustifolium (Oenotheraceae) as the most important secondary host plant instead of Knautia arvensis in northern Sweden and Finland [5]. This aphid is occasionally observed on the other Rosaceae such as Fragaria, Geum, Pyrus, Malus, and Rubus in summer [4, 5]. Furthermore, late in summer, the rose aphid may also be seen on Ilex aquifolium [5, 8]. In 1990-1996, Ripka et al. collected rose aphid on some plants such as Fontanesia fortunei, Gleditsia triacanthus, Symphoricarpos albus, Symphoricarpos sp., Orbiculatus sp., and Vitex agnus-castus as well as rose plant in Hungary [34].

\section{Place and stage of aestivation and overwintering}

The rose aphid overwinters as alate and apterous viviparous females on the lower surface of leaves and on lower branches of the rose plant in Isfahan. Weekly sampling in winter demonstrated that viviparous females are always observed together with different nymphal instars. It should be added that this aphid is seen reproductively in the cold of winter, so this species reproduces viviparously during the whole winter. Since in our study egg stage and sexual morphs were never observed, it can be concluded that the rose aphid is anholocyclic in Isfahan.

In this study, D. fullonum was identified as secondary host plant for M. rosae. The rose aphid spends the summer as alate and apterous viviparous morphs on this plant. The situation and ecological niche of those aphids that aestivate are different from the colonies of this aphid in other seasons of the year. In summer, because of the high temperature and changes in the physiological conditions of the rose plant, 
the aphids have to leave the roses and migrate to secondary host plants. Dipsacus fullonum has wide, large, and dense leaves, and so it will have intensive canopies and will make a cooler environment with more humidity for the rose aphids.

Aestivating colonies were observed in IUT for the first time in early June 2004. The population of the rose aphid on the secondary host plant reached its maximum in mid-July, and these aestivating aphids remained on the secondary host plants until late October. Aestivating colonies on the secondary host plant have a much smaller population than those on the rose and their colonies seemed to be scattered. The colour of aestivating aphids is different; this change of colour is probably due to the host plant [21]. Aestivating aphids were located and active on the stems and lower surface of leaves of the secondary host plant.

\section{Natural enemies of the rose aphid}

The collected natural enemies of the rose aphid belonged to various groups of arthropods such as insects (Table 1), mites, and spiders.

Table 1. Predators and parasitoids of the rose aphid, Macrosiphum rosae, collected in Isfahan, Iran.

\begin{tabular}{|c|c|c|}
\hline Order & Family & Scientific name \\
\hline Coleoptera & Coccinellidae & $\begin{array}{l}\text { Hippodamia variegata Goeze } \\
\text { Coccinella septempunctata L. } \\
\text { Adalia bipunctata L. } \\
\text { Exochomus nigromaculatus Goeze }\end{array}$ \\
\hline Diptera & $\begin{array}{c}\text { Syrphidae } \\
\text { Chamaemyiidae }\end{array}$ & $\begin{array}{c}\text { Syrphus vitripennis Meigen, } \\
\text { Ischiodon aegyptius (Wied.) } \\
\text { Scaeva albomaculata Macquart } \\
\text { Leucopis glyphinivora Tanas. } \\
\text { Leucopis sp. }\end{array}$ \\
\hline Hemiptera & $\begin{array}{c}\text { Miridae } \\
\text { Anthocoridae }\end{array}$ & $\begin{array}{c}\text { Deraeocoris punctulatus (Fallen) } \\
\text { Deraeocoris } \text { sp. } \\
\text { Orius niger } \text { (Wolff) } \\
\text { O. minuta } \text { L. } \\
\text { Anthocoris limbatus Fieber }\end{array}$ \\
\hline Neuroptera & Chrysopidae & Chrysoperla carnea (Stephens) \\
\hline Hymenoptera & Braconidae & $\begin{array}{l}\text { Aphidius rosae Haliday } \\
\text { Aphidius ervi Haliday } \\
\text { Praon volucre Haliday } \\
\text { Ephedrus plagiator Nees }\end{array}$ \\
\hline
\end{tabular}


In this study, four species of Coccinellidae were identified. Three species including Hippodamia variegata Goeze, Coccinella septempunctata Linnaeus, and Adalia bipunctata Linnaeus belonged to the subfamily of Coccinellinae and Exochomus nigromaculatus Goeze belonged to the subfamily of Chilocorinae. Furthermore, three species of Syrphidae were identified as Syrphus vitripennis Meigen, Ischiodon aegyptius (Wiedemann), and Scaeva albomaculata Macquart; among them, the first one was the dominant species. Two more species of Chamaemyiidae, Leucopis glyphinivora Tanasijtshuk and Leucopis sp., were also collected. Furthermore, some predator bugs of Miridae including Deraeocoris punctulatus (Fallen) and Deraeocoris sp. and of Anthocoridae, such as Orius niger (Wolff), O. minuta Linnaeus, and Anthocoris limbatus Fieber, were identified. One species of predator beetle of the family Cantharidae was also collected. Chrysoperla carnea (Stephens) of Chrysopidae, one species of parasitic mites of Prostigmata (Erythraeidae), and some species of predator spiders were also collected.

The most active and important parasitoid wasps of the rose aphid belong to the Braconidae. In this study, four species of parasitoid wasps of the family Braconidae, namely Aphidius rosae Haliday, Aphidius ervi Haliday, Praon volucre Haliday, and Ephedrus plagiator Nees, were collected. Aphidius rosae is one of the most important natural enemies of $M$. rosae in many parts of the world like Germany, Australia, and Poland [11, 32, 35, 36]. This parasitoid is specialized on M. rosae and is rarely active on other aphids [36]. Aphidius rosae has been reported for the first time by the authors in Iran [37]. These parasitoids are found in spring during April and May to early June. In autumn, they are active from November to early December. Pachyneuron aphidis (Bouche) of Pteromalidae was collected as hyperparasitoid of the rose aphid.

\section{Conclusion}

Bioecological studies and interaction between a pest and its environment is very important because the relationship between the pests and environmental factors should be recognized at first for a correct and effective control. Any effective control of pests requires a precise knowledge of their dynamics and factors, such as temperature, which influence them. Temperature is an important environmental variable that affects the rate of aphid development, reproduction, mortality, and survival [30]. At present, in most regions of the world, determining the suitable time for controlling pests is based on the seasonal fluctuations of the pest 
population and it is a subject about which we tried to describe some important points on the fluctuations of the rose aphid population in this study.

\section{References}

[1] Larson, R. A. (1992), Introduction to floriculture. Academic Press, Inc.

[2] Blackman, R. L., Eastop, V. F. (2006), Aphids on the world's herbaceous plants and shrubs. London, UK John Wiley \& Sons.

[3] van Emden, H. F., Harrington, R. (eds) (2007), Aphids as crop pests. CABI: Wallingford.

[4] Blackman, R. L., Eastop, V. F. (2000), Aphids on the world's crops (An identification and information guide), second ed. London, UK John Wiley \& Sons.

[5] Heie, O. E. (1994), The Aphidoidea (Hemiptera) of Fennoscandia and Denmark, Volume V. Family Aphididae: Part 2 of Tribe Macrosiphini of Subfamily Aphidinae, Fauna Entomologica Scandinavica, The Netherlands E. J. Brill.

[6] Maelzer, D. A. (1977), The biology and main causes of changes in numbers of the Rose Aphid, Macrosiphum rosae (L.), on cultivated roses in South Australia, Australian Journal of Zoology 25, 269-284.

[7] Alford, D. V. (1999), A textbook of agricultural entomology, Blackwell Science Ltd.

[8] Alford, D. V. (1991), A colour atlas of pests of ornamental trees, shrubs and flower. Wolfe Publishing Ltd.

[9] Behdad, E. (1988), Pests and diseases of forest trees and shrubs and ornamental plants of Iran, Neshat Publishers.

[10] Rhomberg, L. R., Joseph, S., Singh, R. S. (1985), Seasonal variation and clonal selection in cyclically parthenogenetic rose aphids (Macrosiphum rosae), Canadian Journal of Genetics and Cytology 27(2), 224-232.

[11] Tomiuk, J., Wohrmann, K. (1980), Population growth and population structure of natural populations of Macrosiphum rosae (L.) (Hemiptera, Aphididae). Zeitschrift fur Angewandte Entomologie 90, 464-473.

[12] Jacques, B., Iperti, G., Lapchin, L. (1996), The use of Harmonia axyridis larvae (Coleoptera: Coccinellidae) against Macrosiphum rosae (Hemiptera: Sternorrhyncha: Aphididae) on rose bushes. European Journal of Entomology 93, 59-67.

[13] Jaskiewicz, B. (2006), The effect of the feeding of Macrosiphum rosae (L.) and Chaetosiphon tetrarhodus (Walk.) on the flowering of roses. Acta Agrobotanica 59(1), 515-520.

[14] Khaliq, A. (2003), Impact of plant phenology and coccinellid predators on the population dynamic of rose aphid Macrosiphum rosaeiformis Das (Aphididae: Homoptera) on rose. Asian Journal of Plant Sciences 2(1), 119-122.

[15] Ghosh, A. K., Mier Durante, M. P., Nieto Nafria, J. M. (1994), Distribution of aphid fauna (Homoptera: Aphididae) in the north of Orocantabrian phytogeographic province, Spain. Boletin Asociacion Espanola Entomologia 18(3-4), 81-91.

[16] Jaskiewicz, B. (1997), Observation on the occurrence of the rose aphid (Macrosiphum rosae L.) on bushes of Rosa rugosa Thunb. and $R$. canina L. Folia Horticulturae 9, 25-31.

[17] Eastop, V. F., Hodjat, S. H. (1980), Key to the genera of aphids in Khuzistan. Journal of Agricultural Sciences 7, 53-71.

[18] Eastop, V. F. (1961), A study of the Aphididae (Homoptera) of West Africa. London, William Clowes and Sons Ltd.

[19] Hodjat, S. H. (1993), A list of aphids and their host plants in Iran. [ed. G. Lampel, Ahwaz], Iran Shahid-Chamran University Printing \& Publication Center.

[20] Douglas, A. E. (1993), The nutritional quality of phloem sap utilized by natural aphid populations. Ecological Entomology 18(1), 31-38. 
[21] Dixon, A. F. G. (1998), Aphid ecology: an optimization approach, $2^{\text {nd }}$ ed. London, Chapman \& Hall.

[22] Awmack, C. S., Leather, S. R. (2002), Host plant quality and fecundity in herbivorous insects. Annual Review of Entomology 47(1), 817-844.

[23] Feng, M. G., Chen, C., Shang, S. W., Ying, S. H., Shen, Z. C., Chen, X. X. (2007), Aphid dispersal flight disseminates fungal pathogens and parasitoids as natural control agents of aphids. Ecological Entomology 32, 97-104.

[24] Mehrparvar, M., Hatami, B. (2007), Effect of temperature on some biological parameters of an Iranian population of the rose aphid, Macrosiphum rosae (Hemiptera: Aphididae). European Journal of Entomology 104(3), 631-634.

[25] Zahedi, K. (1999), Summer crops and ornamental plants pests and control in Iran. Iran, University Press.

[26] Barton, B. T., Ives, A. R. (2014), Direct and indirect effects of warming on aphids, their predators, and ant mutualists. Ecology 95(6), 1479-1484.

[27] Brabec, M., Honěk, A., Pekár, S., Martinková, Z. (2014), Population dynamics of aphids on cereals: Digging in the time-series data to reveal population regulation caused by temperature. PLOS ONE 9(9), e106228.

[28] Braendle, C., Davis, G. K., Brisson, J. A., Stern, D. L. (2006), Wing dimorphism in aphids. Heredity 97(3), 192-199.

[29] Brisson, J. A. (2010), Aphid wing dimorphisms: linking environmental and genetic control of trait variation. Philosophical Transactions of the Royal Society B-Biological Sciences 365(1540), 605-616.

[30] Mehrparvar, M., Zytynska, S. E., Weisser, W. W. (2013), Multiple cues for winged morph production in an aphid metacommunity. PLoS One 8(3), e58323.

[31] Diehl, E., Sereda, E., Wolters, V., Birkhofer, K. (2013), Effects of predator specialization, host plant and climate on biological control of aphids by natural enemies: a meta-analysis. Journal of Applied Ecology 50(1), 262-270.

[32] Waterhouse, D. F., Sands, D. P. A. (2001), Classical biological control of arthropods in Australia. CSIRO Entomology, Australian Center for International Agricultural Research.

[33] Ghahreman, A. (1994), Plant systematics, Cormophytes of Iran, vol. 3. Iran University Press.

[34] Ripka, G., Reider, K., Szalay-Marzso, L. (1998), New data to the knowledge of the aphid fauna (Homoptera: Aphidoidea) on ornamental trees and shrubs in Hungary. Acta Phytopathologica et Entomologica Hungarica 33, 153-171.

[35] Wiackowski, S. K., Wiackowska, I., Mezyk, Z. (1997), Aphids (Homoptera, Aphidoidea) and parasites of aphids (Hymenoptera, Aphidiidae) occurring on ornamental plants. Zeszyty Nankowe Instytutu Sadownictwa i kwiaciarstwa w skierniewicach 4, 191-195.

[36] Stary, P. (1973), A review of the Aphidius - species (Hymenoptera, Aphidiidae) of Europe. Annotationes Zoologicae et Botanicae 84, 1-85.

[37] Mehrparvar, M., Hatami, B., Stary, P. (2005), Report of Aphidius rosae (Hym.: Braconidae), a parasitioid of rose aphid, Macrosiphum rosae (Hom.: Aphididae) from Iran. Journal of Entomological Society of Iran 25(1), 63-64. 